\title{
School Examinations leakage: Case of Zimbabwe Schools Examinations Council
}

\author{
${ }^{1}$ Isao Mashanyare,${ }^{2}$ Emmanuel Chinamasa \\ ${ }^{I}$ (Masvingo Education Provincial Officer) \\ ${ }^{2}$ (Chinhoyi University of Technology)
}

\begin{abstract}
The purpose of this study was to find ways of reducing school examinations leakages in Zimbabwe. It was motivated by the observation that, school examinations are leaking in Zimbabwe. The government is loosing thousands of dollars when replacing papers that would have leaked. Zimbabwe uses a centralized examinations system hence a leak of one paper affects the whole nation. The study applied a descriptive survey. Data was collected from ZIMSEC officials, school heads and teachers and students using a self reporting questionnaire, students' essays and an analysis of news paper reports. The study found that, examinations leaking can occur from the minister of education down to the classroom teacher. Question papers can leak as soft in hard copies. A leaked paper can be identified by a high pass rate off the norm, by a group of students who show identical presentation of solutions to the examinations questions. Study revealed that, school heads and teachers are not employed by ZIMSEC to transport and administer examinations. They are not paid for such services which they carry out on their expenses. Factors contributing to schools examinations leakage include, use of public transport, lack of security from district examinations centers to schools and a demotivated teaching force working grudgingly for ZIMSEC. The study recommends that, teachers be paid for the services that they render to ZIMSEC because they are not employees of ZIMSEC. There is need for ZIMSEC to contract transport providers for examination papers from district centers to each school. ZIMSEC can form a security unit to cater for examinations leakages. There is need for debates on examinations leakages on mass media to raise public awareness.
\end{abstract}

Key Words: Examination leaking, ZIMSEC, Managing schools

\section{Introduction}

Examinations leakage is a bit different from examinations cheating. In this study, examinations leakage refers to the illegal filtration of an examination question paper from its system or accessing of the examination question paper by a candidate before the paper is officially opened in the examination room. This can occur anywhere between the setting of the examination paper and the opening of the examinations question papers in the presence of the candidates in the examinations rooms.

Examinations are used as a tool for objectively evaluating and assessing students' learning outcomes, ability to demonstrate knowledge, understanding and potential for other employment skills development. Actions and practices that undermine the credibility of examinations pose a serious threat to the quality of the education system and the attainment of its selective goals. Examination leakages are an example of such actions that threaten the integrity of examinations and damage the authority of those responsible for conducting them. In Zimbabwe, were a centralized examination system is used, examination leakages are a serious problem. It affects candidates in the whole country.

Soon after independence in 1980, Zimbabwe reformed its education system to align it with new national goals. Before independence, Zimbabwe's public school examinations depended heavily on United Kingdom (UK) based examinations boards. The Ordinary and Advanced level examinations were the preserve of several external examination boards such as the University of Cambridge Local Examination Syndicate (UCLES), the University of London Schools Examinations Board (ULSEB) and the Associated Examinations Board (AEB). Zimbabwe, the then Rhodesia, had its own Examinations branch under the Ministry of Education, Division of African Education, which, besides playing an administrative role for external examinations, also administered the terminal primary school grade seven (7) examinations, the Junior Certificate examinations, the F2 grade nine (9) and grade eleven (11) examinations meant for African students.

From a political angle Musarurwa and Chimhenga (2011),charges that, different examination boards were for different students. Associated Examination Board (AEB) was meant for whites while University of Cambridge Local Examinations Syndicate (UCLES) was mainly used by African students. The discriminatory purpose of the assessment system was meant to disadvantage majority of the African population. Due to this highly selective system, Zimbabwe was determined to take control of its examinations soon after independence in 1980 to address the disparity. It lacked faith in the previous examination process that led to the localization of 
examinations between 1984 and 1994 with emphasis initially on 'O' level examinations. AEB examinations were gradually phased out while UCLES took over all examinations and assisted with localization.

The Zimbabwe School Examinations Council (ZIMSEC) was established through an Act of Parliament (Zimbabwe School Examinations Act of 1994) as the body responsible for assessment in primary and secondary education in Zimbabwe. ZIMSEC then took over activities from the Exams Branch in Zimbabwe and the Cambridge Local Examinations Syndicate (UCLES) of the United Kingdom (UK). The ZIMSEC Act (17/1994 and 22/2001) empowered ZIMSEC to:

a) Organize and conduct such examinations in subjects that form part of a course of primary or secondary education as the Ministry may direct in writing.

b) Consider and approve subjects suitable for examination,

c) Appoint panels or boards of examiners

d) Approve and register examination centers

e) Review rules and regulations relating to examinations

f) Confer or approve the conferment of certificates, diplomas and other awards to persons who would have passed examinations,

g) Enter into arrangements with persons or organizations for recognition of certificates, diplomas and other awards granted in respect of examinations organized or conducted by the Council

h) Do all things necessary to maintain the integrity of the system of examinations in respect of primary and secondary education in Zimbabwe. The integrity of ZIMSEC can only be maintained when there is maximum security of the examinations and when the examinations are run professionally without leakages.

i) Do any other thing that the Council may be required to do under the Act or any other enactment. This allows ZIMSEC to implement findings from this study to reduce cases of examinations leakages.

The localization of examinations was completed in 2002 when ZIMSEC finally took over the control of Advanced level examinations. Its functions includes: setting, distribution, training of markers, security of examinations and marking of school examinations. Though it still falls under the Ministry of Primary and Secondary Education, ZIMSEC is an autonomous board controlled by a Board of directors representing different stakeholders in society with an interest in education. It remains funded through a government vote, examination fees, as well as its own fund-raising projects. It should be noted that, school heads and teachers are not employees of ZIMSEC. Although in Rhodesia examinations invigilation was paid for by the examining boards, it is surprising to note that, today teachers are expected to transport, keep, administer, invigilate and return examinations answer scripts to ZIMSEC district offices at their own expenses. Those teachers who mark examinations are employed on contract basis and paid for the marking.

\section{Forms of malpractices in public school examinations}

According to the World Bank Group (2001) malpractice in public examinations is "a deliberate act of wrong doing, contrary to official examination rules, and is designed to place a candidate at an unfair advantage or disadvantage".

The following table 1, summarizes the more general forms of examinations malpractice experienced world wide:

\begin{tabular}{|l|l|l|}
\hline Development & \multicolumn{1}{|c|}{ Description } & \multicolumn{1}{|c|}{ Involvement } \\
\hline Leakage & Contents of the examination disclosed & $\begin{array}{l}\text { Usually involves teachers, examiners, } \\
\text { printers, proofreaders or school administrators }\end{array}$ \\
\hline External assistance & $\begin{array}{l}\text { Unauthorized assistance to candidates } \\
\text { during } \\
\text { examinations }\end{array}$ & $\begin{array}{l}\text { Involves invigilators, writing answers on the } \\
\text { blackboard, circulating sheets of work during the course } \\
\text { of the exam }\end{array}$ \\
\hline $\begin{array}{l}\text { Smuggling of foreign } \\
\text { Materials }\end{array}$ & $\begin{array}{l}\text { "crib notes", charts and answer } \\
\text { booklets. } \\
\text { Frequently smuggled in pants, shoes, } \\
\text { hems or parts of the body }\end{array}$ & \\
\hline
\end{tabular}

(Adapted from the World Bank Group, 2001)

The World Bank Group (2001) further indicates that learners get involved in examination irregularities and malpractice mainly because, success in a public examination can have profound, immediate and long-term impact on a candidate's life. In many developing countries, examination success and secondary school graduation represents the sole avenue for poor students to secure a non-menial job. TechTalk, (2001) concluded that, large-scale testing is not the culprit, it is large-scale testing with high stakes attached to the results that, in some instances have resulted in cheating. This study is more interested in examinations leaking. Chinamasa et. al (2011) dealt with the other two under examinations cheating. 


\section{Examination leakages in other countries}

Examinations leakage is a problem not only peculiar to Zimbabwe. In Egypt, three "A" level examination papers had to be pulped amid concerns that the content could have leaked out. A report by Clark (2012) alleged that copies of the papers were mixed with batches of past examination papers sent out to schools in Egypt which requested them from Edexel GCE (Britain) for pupils to use in revision sessions. Three "live" "A" level papers were sent by mistake before they had been written. This basically confirms that some examinations leakages start from the distribution point.

A South African newspaper, The Star of 9 October 2013, had a report by Otsialo in which the Mandera East police boss, Rotich, was assuring teachers and candidates of maximum security during the national examination period. This was after teachers had expressed fear during the examination period since some parents had collided with Heads and Principals to force those who supervise the examinations to allow cheating in their centers. It also made reference to a school Principal who was killed by militia on his way to collecting examination papers in 2012. It was alleged that the militia wanted to force the Principal to leak examinations so that candidates could cheat in examinations without reproach. These events show that examinations leakage can be a collaborative activity.

In Zambia, examinations have been leaking in various ways. According to the Zambian Watchdog, (2013) senior officers at the Examination of Zambia offices have secrete codes for examinations storage banks including the website password which contain all grade 7, 9, and 12 examination papers in soft copy. It is alleged that these codes are circulated professionally to some senior officers in the Ministry of Education including some Ministers who print out these examinations for their family members. The Zambian Watchdog further claims that these papers are sold off to some members of public in both soft and hard copies. The edition cited an example of the Zambian Chemistry paper (5124/2) and Mathematics syllabus D, for the 2012 examinations, which were leaked through some senior political officials who managed to buy the papers for their children at Kabulonga Girls and Munali Boys. It further alleged that general commoners in public schools only get these papers through pupils who seek help from other pupils. One can conclude that technology can also be used to facilitate examinations leakage.

\section{Examination Leakage in Zimbabwe}

Probably school examinations may have been leaking although they did not receive much publicity before localization of examinations. Possible factors contributing to limited publicity of school examinations leakage include: information censorship by the foreign examiners for integrity maintenance, strong adherence of officials to the official secrecy act and limited public access to the media. In Zimbabwe the need to adhere to transparency standards call for the publication of any issues related to the taxpayer's money. This requirement encourages researchers and the mass media to publish issues of examinations leaking. It is a public good.

Makamure (2005), in The Standard Newspaper, took the lead by claiming that writing examinations was a nightmare in Zimbabwe. She alleged that since ZIMSEC had taken over the administration of examinations in 1998, standards had plummeted. She cited a scandal which involved the late former Minister of Education, Edmund Garwe's 14 year old daughter who leaked a Zimbabwe Junior Certificate History examination paper to friends and schoolmates at a high school in Harare in 2004. This was after the then Minister of Education had taken the paper to his home before examinations had been written

The same article reported that in 2005, ZIMSEC withheld "O" level Chemistry results for Gokomere High school following suspicion that a teacher had leaked the paper. It was alleged that the teacher had taught his class exactly what was in the ZIMSEC Chemistry examination the day before the examination.

The Voice of America-Zimbabwe (2006) alleged that in October 2006, "O" level examinations were stolen from a Headmaster in Karoi, Mashonaland West, by a man to whom he had given a ride in his car. The same article also reported that in Kwekwe District, schools failed to receive scanner examination answer sheets from ZIMSEC on time. Grade seven (7) pupils wrote their answers on ordinary paper and teachers later transposed pupils' answers on scanner sheets when they got them. This process raises the possibility of answer alterations in the process. The public can question the validity and reliability of such grade seven results for those pupils.

Kombora (2007), alleged that government decided to go ahead with "O" and " $\mathrm{A}$ " level examinations in October/November 2007 although a lot of question papers had already leaked after examination papers fell off a vehicle and scattered along Simon Mazorodze road in Harare the previous week. Examination papers had fallen off a vehicle at a traffic circle along the Harare-Masvingo road and had been picked by members of the public. This was after the vehicle's tailgate had accidentally unhinged releasing cartons containing examination envelops.

The Zimbabwe Daily News (2010), reported that ZIMSEC had launched an internal investigation following indications that a November 2009 "O" level Mathematics paper was leaked. This was suspected after results which had been released showed an unusually high pass rate and candidates identical solutions in the 
subject. A ZIMSEC official was quoted alleging that there were some suspicions that some employees were selling examination papers before they were written.

According to ZIMDIASPORA (2012), a private College in Harare was investigated over "O" level examination leakage. The paper reported that ZIMSEC was investigating a private college in Harare after 126 "O" level Mathematics results had raised suspicion of examination leakage due to the unusual high pass rate which had been recorded at the college. This caused inconveniences when ZIMSEC withheld the June 2012 results for the centre while parents wanted their children to apply for tertiary education. Some parents even threatened to drag both the examinations centre authorities and ZIMSEC to court over the issue.

The New Zimbabwe News paper of 18 October 2012 had a headline which read "ZIMSEC withdraws 13 leaked examination papers." The paper reported that ZIMSEC was facing a US\$850 000-00 bill to replace the leaked papers. This was after a Head from Matabeleland North school had misplaced examination papers while hitch-hiking from Bulawayo to his school on a Sunday.

What can be deduced so far is that, the mass media is reporting examinations leakage in Zimbabwe, examinations leakage is through officials (from the minister to the classroom teacher). Leaking of examinations can be shown by an unusually high pass rate (which is off the norm) of candidates at the centre or in a particular paper. Identical answers can also hint examinations leakage. Technology can be used to facilitate examinations leakage. Examinations leakage can be an individual or collaborative activity. Mode of examinations transportation is also a factor contributing to examinations leakages. It is costly to the nation to replace leaked examination papers, hence it should be everybody's concern.

ZIMSEC has been writing circulars and memos to centre heads on regulations and conduct of examinations. Regional Examinations Circular Number 3 of 2011 reminded heads of examination centers of proper administration of public school examinations and avoiding all forms of cheating. Unfortunately the real problem was more on examinations leakage than cheating. ZIMSEC Examinations Circular Number 37 of 2012 encourages heads of schools to pool resources together where applicable and hire transport so that they avoid use of public transport when ferrying examinations. Regional Examinations Circular Number 1 of 2012 emphasized that the keys to the strong room should be handled by members of staff not bursars or clerks during the examination sessions. The real issue was not on loss of examination papers from the strong room but leaking before they got in the examinations strong room. These cases show that, ZIMSEC circulars are addressing general areas and not the core problem of examinations leakage.

Currently ZIMSEC delivers public school examination papers to District centers and all schools/centers come to collect their papers from the District centre to their stations using their own means of transport. Although school heads are not ZIMSEC employees, they are held accountable for examinations leakage. In fact they are supposed to inventory them by checking on content and quantity then place the sealed packages back into the boxes according to the dates they will be written. The boxes are stored in an approved safe until the day of the examination. Packages are not supposed to be opened until shortly before the examination is to be written.

Responding to the question on security measures which are in place at ZIMSEC to protect National examinations, ZIMSEC website (2013) indicated that all ZIMSEC examination question papers were protected by stringent security measures at all points of production, distribution, storage and at all transit points.

Examination papers were guarded at cluster distribution centers by state security and ZIMSEC security details. However, security is guaranteed mainly up to the collection point by centre heads and very little has been done to protect the papers from the collection point to centers were the examinations will be written. Heads have just been taking examination papers and use any means of transport to get the papers to their stations. Answer scripts are delivered to ZIMSEC Regional centers using any means of transport thereby increasing the risk of losing the papers. Unfortunately no school head is paid for the collection of examination papers and taking answer scripts to ZIMSEC. One can infer that Heads are not motivated to do ZIMSEC duties diligently.

\section{Statement of the Research problem}

Zimbabwe School Examinations Council has experienced problems of school examinations papers leaking. In 2010, Chongogwe High school in Chivi district lost four different ' $O$ ' level public school examination papers which led to the suspension of the papers, reprinting and rescheduling the examination time table. Examinations leakage has had serious negative effects on the ZIMSEC budget, schools are equally affected when examination time tables are rescheduled, especially boarding schools which have to keep students a little longer than the planned time. In addition, the credibility of Zimbabwe's examination standards is compromised due to negative publicity when public examination papers are not handled properly. Examinations leaking also tarnish the image of the country's education system as some people are tempted to conclude that Zimbabwe's examining board is incompetent. While some strategies such as sending examination papers direct to schools, using cluster centers and writing circulars and memos were put in place, accountability 
still remains a problem. The current study intends to suggest strategies to reduce examinations leaking from practitioners (school Heads and ZIMSEC officials) and the candidates themselves.

\section{Research Objectives}

The study intends to: (1) Establish factors contributing to school examinations leakage.

(2) Suggest strategies which can be adopted to reduce cases of examinations leakages.

\section{Significance of study}

This study is important in that, it sought to improve the security of public schools examinations. It is a source of debate on the leakage of public school examinations. Its' findings will come handy if examinations leakages occur in the District and the researchers are tasked to make investigations. The researchers can also assist Ministry of Education officials in coming up with intervention programmes on the reduction of examination leakage.

\section{Research Design}

\section{Research Methodology}

This study used the descriptive survey research design to facilitate researchers' description of cases of examinations leaking in Zimbabwe. Surveys had the following advantages: (1) It enables the collection of primary data from a large population which cannot be observed directly. Zimbabwe Schools Examination Council has many examination centers which cannot all be reached out therefore a survey enables a small group to be used from which the findings can be generalized to similar cases. Robson, (1995) supports the idea by saying that survey methods may be adapted to collect generalisable information from almost any large human population. (2) surveys provide an excellent opportunity for a measurement of motives or orientations. In this case surveys help identify motives for leaking school examinations. (3) If the survey is properly conducted, the results are reliable and representative of a much wider population. (4) Surveys can be extremely efficient at providing large amounts of data at relatively low cost in a short period of time. (5) Surveys allow anonymity which can encourage frankness when sensitive areas like leaking of school examinations are involved.

However, the survey method raises some ethical issues. The participants may refuse to participate in the study or be suspicious of the ultimate results of the findings. Therefore they may provide inaccurate data which they consider to please the researchers.

\section{Population and Sampling}

The population of this study was composed of primary and secondary school heads, ZIMSEC and Ministry of Education officials and "O" and "A" level students. These are directly involved in the running of public school examinations hence their contribution to the study was vital. Students are the main beneficiaries and affected population when examinations leak. The total sample frame for this population is known, hence probability sampling is applicable. Researchers assumed that the variable, leakage of school examinations depends on the level of the respondent within the official hierarch of ZIMSEC, hence stratified sampling is required to cater for the quantitative variation within the population.

The researchers obtained a list of examination centers in Zaka District from the ZIMSEC Regional offices and the ED46 returns from the District Education Officer in Zaka. Sampling started by applying proportional sampling from level to level. Then simple random sampling was applied by matching the last three digits of a centre number to a random number generated by a computer. Samples of size $(n=25)$ cluster schools was raised. Simple random sampling of $(n=55)$ school heads and teachers, $(n=94)$ students and $(n=61)$ Education and ZIMSEC officials provided data for this study.

\section{Research Instruments}

The main instrument used for this study was the questionnaire designed by the researchers for this purpose. Questionnaires were ideal for sensitive issues like examinations leaking which require respondent confidentiality and anonymity. Participants for this study were literate and individual views were required. In addition, questionnaires were kept for analysis later. They capture and store data in its original form given by the respondent. The second set of instruments was composed of news papers case reports. These provided media perceptions of the problem of examinations leakage. These were analyzed for examinations leakage frequencies, distribution and case circumstances.

Students were requested to write an essay entitled, "Strategies to reduce school examinations leakages in Zimbabwe." The essay allowed students to bring out incidences, contributing factors and strategies. These captured students' real understanding of the problem and problem solving skills. Essays were ideal instruments for analysis and record storage. Focus Group Discussion guides were used to capture group views. 


\section{Data Collection and Analysis}

Permission was sought from ZIMSEC Director and the Ministry of Primary and Secondary Education for the researchers to collect data from ZIMSEC officials and schools. Two self reporting questionnaires were completed by Centre heads, deputy heads and ZIMSEC officials. These were also given to respondents in person by researchers during the Heads' meetings. This gave the researchers the opportunity to explain to the respondents the purpose of the study thus allaying the fear that the study could be an investigation for publication in the media. The researchers also personally collected the completed questionnaires to reduce time lapse between dispatch and collection of completed questionnaires. The move also minimized the problem of non-returns. Researchers visited news paper libraries on the internet for cases of examinations.

The researchers interviewed some selected students and collect data while interviewing them as a group. The students were interviewed separately from the heads. A group of students was brought in a classroom to have a free flowing, but focused, discussion on the issue of examination leakages. The respondents were drawn from form three to upper six students. Researchers explained to the respondents the purpose of the study and the importance of their contribution to the study. Before the researcher started the panel discussions, the students determined and agreed on time to spend in the discussion. In addition to the data collected or notes written by researchers, students were asked to write compositions about leakage of examination papers focusing on strategies to improve the security of examination papers.

Data collected from population, source and by instrument triangulation was analysed by identifying emerging themes and recording them according to research objectives. Findings were presented below.

\section{Findings and Discussions}

Table 2, Participants' distribution by Age.

\begin{tabular}{|l|l|l|l|l|l|l|}
\hline Group & $19-25$ & $26-30$ & $31-40$ & $41-50$ & $51-60$ & Total \\
\hline Teachers & 0 & 4 & 31 & 15 & 5 & 5 \\
\hline ZIMSEC & 2 & 9 & 21 & 22 & 7 & 61 \\
\hline Students & 76 & 18 & 0 & 0 & 37 & 0 \\
\hline Total0 & 78 & 31 & 52 & 12 & 94 \\
\hline
\end{tabular}

If the age of majority in Zimbabwe is applied, all the participants are above 18 years, hence adult enough to make decisions which can influence policy at national level. All of them had written at least the grade seven and form four examinations, hence rich sources of the study variable. Their experiences provide rich sources of factors and suggestions.

Table 3, Mode of Examination paper transport from district to school $\quad \mathrm{N}=\mathbf{5 5}$

\begin{tabular}{|l|l|l|l|}
\hline Mode of Transport & Primary & Secondary & Total \\
\hline School Vehicles & 4 & 3 & $7 \quad(13 \%)$ \\
\hline Personal Vehicles & 7 & 6 & $13(24 \%)$ \\
\hline Public (Buses and Combs) & 16 & 9 & $25(63 \%)$ \\
\hline Total & 37 & 18 & 55 \\
\hline
\end{tabular}

The majority of participating schools have no formal methods of transporting examinations question papers from district centers to their schools. This seems to indicate that use of public transport was a serious risk. From this angle, researchers empathized with the two school heads who lost examination question papers on transit from district centers to their schools. These findings also show that school heads are using their personal vehicles for school business. Researchers noted that, education is probably the only sector where employees use their personal properties to support the employer. Unfortunately disturbing comments and charges are raised when examinations question papers are lost on transit. Consider the comments in italics for the two cases below.

\section{Case ONE}

The acting school head of Sijaugwe Secondary school lost a carton containing 13 different papers 2012. It is alleged that the acting head used public transport to ferry the examination papers to the school. He only noticed that he had missed the carton after he had travelled some distance from Bulawayo, the collection centre. The papers had to be reprinted. ZIMSEC had to incur huge costs to replace the papers. This could be attributed to poor transport systems since the acting head was using public transport. The other contributory factor could be negligence on the part of the acting head. He should not have put the question papers in the trailer of the bus but rather keep them where he was seated and ensuring that as passengers were dropped, the carton remained in the bus. 


\section{Case TWO}

In 2006, a Karoi school head lost examination papers to a passenger he had given a ride in his car. This could have been due to negligence on the part of the school head who should have been vigilant enough when ferrying examination materials. This could have been avoided if the head had not carried examination papers as well as passengers in his car.

In case two despite the fact that, the school head is not an employee of ZIMSEC, carrying examination question papers is already imposing restrictions on his use of his personal vehicle. Charges of negligence in the two cases need to debated by all stake holders for policy improvement. Minister of Education, Garwe E, was negligent to the extent of allowing his 14 year old daughter to access the ZJC paper that the minister had taken home. Negligence could also result from the ZIMSEC officials when they pack wrong papers or deliver papers in unsecure vehicles. According to Clark (2012), three "A" level examination papers had to be pulped in Egypt when 'live' papers were mistakenly sent together with past examination papers which had been requested for revision purposes by some schools from the Examination Board

Table 4, Factors contributing to Public School Examinations leakages $\quad \mathbf{N}=230$

\begin{tabular}{|l|l|}
\hline Factor contributing to Examinations leakages & Frequency \\
\hline Use of public transport from district centers to schools & 168 \\
\hline Negligence on the part of the school heads & 98 \\
\hline ZIMSEC focusing more on examinations invigilation rather than leaking & 93 \\
\hline Public pressure for good results & 93 \\
\hline Incompetent teachers who did not complete syllabuses & 90 \\
\hline Schools ranking and results based rewards & 86 \\
\hline Printing and dispatch loopholes & 80 \\
\hline Ready market for leaked question papers & 77 \\
\hline Lack of employment contract between ZIMSEC and school heads /teachers & 69 \\
\hline
\end{tabular}

The majority of respondents raised the leakage of examination papers due to use of public transport. One can attribute this variable to the fact that, such cases are caught by the media. This study recommends that, ZIMSEC contracts the delivery of examinations question papers to individual schools. A particular contractor can be in charge of a cluster of schools. In addition the contractor should provide security to the question papers. Alternatively, loan facilities could be availed for school heads or schools to purchase vehicles which they can use for ZIMSEC businesses.

Negligence is a relative term. In this case it could have been justified if heads lost the papers while drinking beer. It can account for the a report by Kombora (2007), who alleged that some examination papers fell off a vehicle at a traffic circle along the Harare-Masvingo road and had been picked by members of the public. This was after the vehicle's tailgate had unhinged releasing cartons containing examination envelops. This form of error (unsecuring of the tailgate) could be called negligence.

School heads raised concerns of being "abused" by their Ministry of Education Sport and Culture which required them to transport examinations question papers, invigilate examinations and transport answer scripts for ZIMSEC, when they were not employed by ZIMSEC. They did not understand why they were not paid for their services when candidates paid full examinations fees to ZIMSEC and not the Ministry of Education, Sport and Culture.

\section{Study Recommendations}

In light of the findings by researchers suggested the following strategies:

1. ZIMSEC use the mass media like television and news papers to educate members of the public on the dangers of leaking examinations. Appeals for the members of the public to cooperate and report any leakages could be made on the media. Chances are high that once adequate advocacy was done, cases of examination leakages would be reported promptly.

2. Another strategy was for ZIMSEC and centers to form what respondents termed "student intelligence committees" which would interlink with and identify individuals who cheat. If properly constituted, the committee would help in detecting students who could have had access to examination papers before they are written.

3. ZIMSEC can form a security unity which provides security examination papers from district centers to schools.

4. It was also suggested that ZIMSEC should pay for examination transportation and administration so that teachers are motivated to run examinations without being tempted to leak them.

5. Respondents suggested that ZIMSEC could develop a system of coding all examination papers so that a report would be send electronically to ZIMSEC if any paper is opened before time. This could be some form of surveillance system which ZIMSEC has been using when transporting examination materials from the printing companies to collection points.

6. ZIMSEC can improve the security systems of transporting examination materials to centers. Preferably examination papers should be delivered to centers by ZIMSEC using the Council or government 
vehicles. Being a national programme, it should be possible for government vehicles to be used for the exercise during the examinations period.

\section{References}

[1]. Chinamasa, E.et al. (2011). Examinations cheating: Exploring strategies and contributing factors in five universities in Zimbabwe. Journal of Innovative Research. 1(1), 86-101.

[2]. Denga, I.D \& Denga H.M (1998). Educational malpractice and cultism in Nigeria. Calabar: Rapid Educational Publishers Limited.

[3]. Dooley D. (1990) Social Research Methods. Prentice Hall Inc, Eaglewood Cliffs, New Jersey Evans, E.D. \& Craig, D. (1990b) Adolescent cognition for academic cheating as function of grade level and achievement status. Journal of Adolescent Research. 5, $325-345$.

[4]. Ezezogor, S.A. (1982). West African Examination leakages. Journal of all Nigerian conference of rincipals of secondary schools. $21,130-137$

[5]. Gay, R. (2006) Educational Research: Competences for Analysis and Application. Ohio; Merrill Publishing Company.

[6]. Guba P. And Lincolin M. (2004) Research Methods and statistics. McGraw Publishers, New York

[7]. Happner, P.P, Kivligham, P.M and Wampold, B.E.(2003) Research Design in Counseling. California; Brooks publishing company.

[8]. Mckenzi J. And Smeltezer J. (2007) Health Promotion Programs. Allyn and Bacon, Boston

[9]. Nziramasanga Commission (1999) Presidential Commission of Inquiry into Education and Training, Harare, Public Service

[10]. Punch K.F. (2005) Introduction to Social Research; Quantitative and Qualitative Approaches, $2^{\text {nd }}$ Edition, C.P.I. Anthony Rowe, Great Britain.

[11]. Robson, C. (2004) Real World Research. A Resource for Social Scientist and Practitioner Researchers, T.J. Press Ltd, Great Britain.

[12]. Walker R. (2001) Doing Research; A Hand Boook for Teachers, Methuen and Co Ltd, Great Britain.

[13]. Bouville, M. (2007a) Exam fairness, http://arxiv.org/abs/0803.4235.

[14]. Bouville, M. (2007b) Cheating and neutralization, http://www.mathieu.bouville.name/education-ethics/Bouville-neutralizationempiricism.pdf.

[15]. Bouville, M. Why is Cheating Wrong. http://arxiv.org/ftp/arxiv/papers/0803/0803.1530.pdf

[16]. Clark L, (2012) Thousands of "A" level Exam Papers pulped after Security Error. http://www.dailymail.co.uk/news/articles-2158905/Thousands-A-Level-exam-papers-pulped-security-error-means-mistakenly-sentschools-abroad-html\#ixzz2fA03F06G

[17]. DiNapoli, T.P. (2006) Audit-Office of the State Comptroller, htt://www.osc.state.ny.us/audit/allaudit/09307/06s104.pdf, dated 5 June 2007

[18]. Glidden, G. (1996). Assessment irregularities: A discussion guide for current

[19]. issues in test administration. http://www.natd.org/Gliden96.htm. Accessed

[20]. 2005/12/16

[21]. Jones , L.R. (2011) Academic Integrity and Academic Dishonest: A HandBook about Cheating and Plagiarism; http://www.fit.edu/current/documents/plagiarism.pdf

[22]. Maheshwari, V.K. (Dr) (2011) Malpractices in Examinations-The Termites Destroying the Educational Setup http://www.vkmaheshwari.com/WP/?p=310 dated 24 November 2011

[23]. Musarurwa, C. (2011) Credibility of Examinations in Zimbabwe: A reflective Analysis http://www.academia.edu/1643669/CREDIBILTY-OF-EXAMINATIONS-IN-ZIMBABWE-A-REFLECTIVE- ANALYSIS

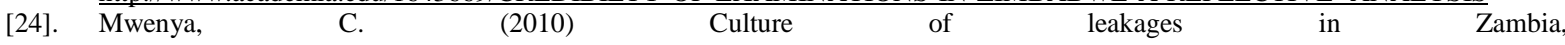
File:///C:/Documents\%20and\%20Settings//hp/Desktop/Africafiles\%20\%20Zambia\%20Education\%20-\%20Culture dated 5 August 2010.

[25]. Newberger, E.H. (2003). The men they will become: The nature and nurture of male character. http://www.elinewberger.com/ dated 5 September 2004

[26]. Nsisong, U. (2013) Remote Causes and Counseling Implications of Examinations; http:/www.studentpulse.com/articles/585/3/remote-causes-and-counselling-implications-of-examination-malpractice.in.Nigeria

[27]. Olatoye, R.A. (Dr) (2001) Checking the menace of examination malpractice: A call for more teaching and learning in schools, http://naere.org.ng/journal/CHECKING-MENACE-EXAMINATION-MALPRACTICE.PDF

[28]. Oniye, A.O. and Alawaye, A.S. (2008) Female Students Perceived Causes of and Solution to Examination Malpractices in ASA Local Government file:///c:/Documents\%20and\%settings/hp/Desktop/FEMALE\%20STUDENTS\%20 PERCEIVED\%20CAUSES\%20 dated 10 June 2008.

[29]. Otsialo M, (2013) Security Assured for Mandera Candidates http://www,the-star-co.ke/news/article-138819/securityassured-mandera-candidates dated 9 October 2013

[30]. The Newsday Zimbabwe (2012) Leakages haunt public exam system http://www.newsday.com.zw/2012/10/26/leakages-hauntpublic-exam-system dated 26 October 2012

[31]. The Sunday News, (2013), ZIMSEC still among the best; http://www.sundaynews.co.zw/index.phd?id=34649\%3Azimsec-stillamong-the-best\&format+\&option=com-content\&Itemid=131 dated 6 April 2013

[32]. The University of the State of New York, (2013) School Administrators' Manual Secondary Level Examinations, hssam-13rev-pdfAdobe Reader

[33]. The World Bank Group. (2001). Public examination system: Topics -

[34]. Malpractice. The World Bank Group. 2001.

[35]. http://www.worldbank.org.education/exams/malpractice/asp. Accessed 2006/02/12

[36]. The Zambian Watch Dog (2013) How examination malpractices are carried out in Zambia http://www.Zambian watchdog.com/how-examination-malpractice-are-carried out in Zambia/ dated 2 September 2013.

[37]. The Zimbabwe Daily News, (2010), ZIMSEC probes "O" level examination leak, http://www.zimbabwesituation.org/?p=10133,

[38]. Umali, B.etal (2012) Factors That Influence Examination Malpractice and Academic Performance in Primary Science among Primary Six Pupils in Cross River State, Nigeria, http://wwwiiste.org/journals/index.php/JEP/article/viewFile/2286/2289

[39]. ZIMDIASPORA, (2012), ZIMSEC Investigates a Private College in Harare, 126 "O" level Mathematics results withheld, www.zimdiaspora.com/index.php?=com,

[40]. Zimbabwe Broadcasting Corporation (2012) Dr Ndlovu Bemoans exam leaks, http://www.zbc.co.zw/news-categories/topstories/24973-dr-ndlovu-bemoans-exam dated 30 October 2012 